DOI https://doi.org/10.30525/978-9934-588-79-2-2.48

\title{
МЕТОДИКА ОРГАНІЗАЦІЇ ТЕХНІЧНОГО ОБСЛУГОВУВАННЯ ТЕХНІКИ ІНЖЕНЕРНИХ ПІДРОЗДІЛІВ ЗБРОЙНИХ СИЛ УКРАЇНИ В ХОДІ ВИКОНАННЯ ЗАВДАНЬ У СКЛАДІ МІЖНАРОДНИХ МИРОТВОРЧИХ КОНТИНГЕНТІВ
}

\author{
Колос О. Л. \\ кандидат технічних наук, \\ дочент кафедри інженерних спеціальних дисциплін \\ факультету підготовки спеиіалістів \\ бойового (оперативного) забезпечення \\ Начіональної академії сухопутних військ \\ імені гетьмана Петра Сагайдачного \\ Семів Г. О. \\ кандидат економічних наук, \\ дочент кафедри ракетно-артилерійського озброєння \\ факультету ракетних військ і артилерії \\ Національної академії сухопутних військ \\ імені гетьмана Петра Сагайдачного \\ м. Львів, Украӥна
}

В процесі експлуатації інженерної техніки деталі машин інженерного озброєння (МIO) зношуються і старіють, що призводить до відмов і несправностей. Все це і визначає основну мету заходів по обслуговуванню техніки в процесі експлуатації - попередити випадки появи відмов в процесі функціонування за призначенням і полягає в проведенні перевірки через визначені інтервали часу стану зразка МIO, заміні деяких деталей, регулюванні параметрів і усуненні виявлених несправностей, тобто будь-яких пошкоджень або відхилень від норм за припустимі межі. Інакше кажучи, технічне обслуговування (ТО) техніки проводиться для попередження виникнення відмов і несправностей в процесі іiі експлуатації.

Відомо, що інтенсивність виникнення відмов і несправностей інженерної техніки безпосередньо залежить від об'єму і складності завдань, інтенсивності використання техніки за призначенням, природногеографічної характеристики місцевості проведення робіт, рівня професійної підготовки та нервово-психологічного навантаження на механіків-водіїв, тобто від конкретних специфічних умов виконання завдань 
інженерними підрозділами. Накопичений досвід багаторічної участі Збройних Сил України в миротворчих операціях свідчить, що всі перелічені чинники, які безпосередньо впливають на інтенсивність виникнення відмов техніки, в районах проведення миротворчих операцій, як правило, суттєво перевищують гранично допустимі значення умов використання, зазначені в експлуатаційній документації на зразки техніки, що знаходяться на озброєнні інженерних військ у складі міжнародних миротворчих контингентів. В зв'язку з цим очевидно, що безвідмовність МIO в таких умовах використання за призначенням суттєво знижується. Як наслідок цього експлуатаційна продуктивність зразків техніки теж понижується. Компенсувати це зниження і зниження ефективності використання техніки інженерних підрозділів в процесі виконання завдань у складі миротворчих контингентів можливо лише шляхом удосконалення організації і проведення ТО техніки.

В роботах [1,2] засобами теорії почасового резервування обгрунтована доцільність використання організаційних простоїв техніки для профілактичного ТО і поточного ремонту з метою підтримання іii надійності на необхідному рівні. Здійснено удосконалення математичних моделей ТО систем з почасовою і структурною надмірністю, що дозволило враховувати реальні можливості щодо використання наявного організаційного резерву часу при різних стратегіях організації робіт ТО. Були отримані аналітичні співвідношення між параметрами цих моделей і проведено їх теоретичне дослідження шляхом оцінки впливу величини резерву часу $\tau_{\text {д }}$, можливостей структурного резервування, а також параметрів і стратегій ТО на комплексний показник надійності зразків машин інженерного озброєння - коефіцієнт їх технічного використання $K_{T B}\left(\tau_{д}\right)$, який найбільш повно характеризує надійність МІО при врахуванні всіх простоїв, пов'язаних з їх ТО і ремонтом.

Все це створило необхідне теоретичне підгрунтя для безпосередньої розробки методики організації і проведення ТО і ремонту техніки підрозділів інженерних військ, використання якої забезпечить підтримання необхідного рівня надійності техніки при виконанні завдань в специфічних умовах міжнародних миротворчих операцій.

Основним призначенням методики є забезпечення розрахунку раціональних значень параметрів організації і проведення технічного обслуговування МIO, які дозволяють підтримувати на необхідному рівні надійність техніки підрозділів інженерних військ України в специфічних умовах міжнародних миротворчих операцій. 
В основу методики покладені запропоновані в [1-4] математичні моделі ТО, розроблені з використанням методів теорії почасового і структурного резервування.

Методика включає наступні етапи:

1. Аналіз обсягу, умов та строків виконання завдань, які покладаються на підрозділи інженерних військ.

2. Оцінка необхідного та реального рівня надійності МIO, задіяних для виконання поставлених завдань.

3. Вибір стратегії організації ТО техніки доцільної для конкретних умов виконання завдань у складі миротворчих контингентів.

4. Виявлення і підрахунок максимально можливого часу організаційних щодобових простоїв МIO як можливого резерву для проведення робіт ТО техніки $t_{\text {MAх рез иасу }}$.

5. Побудова графіку позмінної організації робіт ТО для обраної стратегії обслуговування з метою перевірки можливості використання виявленого резерву часу в повному обсязі при врахуванні медичних обмежень щодо виконання виробничих потреб в вечірнє-нічні періоди доби.

6. Вибір математичної моделі системи ТО з почасовою надмірністю відповідно до задіяної стратегії технічного обслуговування і побудова на іiї основі за допомогою запропонованих алгоритмів і програм, реалізованих в системі MATLAB, графіка залежності коефіцієнту технічного використання від періодичності проведення ТО або періодичності контролю технічного стану МІО при використанні наявного резерву часу і пропускної спроможності існуючої системи ТО щодо обслуговування і ремонту МІО.

7. У випадку, коли розрахунки показують, що шляхом використання тільки почасового резервування необхідне для виконання поставлених завдань значення коефіцієнту технічного використання є не досяжним, необхідно замінити модель ТО з почасовою надмірністю моделлю ТО відповідного виду з почасовим і структурним резервуванням і повторити розрахунки.

8. Побудова графіку залежності середніх питомих витрат на проведення технічного обслуговування МІО як функції від періодичності проведення ТО $\left(T_{T O}\right)$ або періодичності контролю їх технічного стану $\left(T_{K}\right)$ та визначення графоаналітичним способом з використанням побудованих залежностей для коефіцієнта раціональних значень параметрів організації і проведення технічного обслуговування МIO $\left(T_{T O}\right)$ або $T_{K}$ за критерієм мінімуму середніх питомих витрат на проведення відновлюваних робіт МIO. 
9. Сітьове планування та управління проведенням робіт ТО і поточного ремонту основних зразків МІО в одну, дві або три зміни з метою вибору такої організації робіт, яка забезпечить своєчасне виконання різних видів ТО та поточного ремонту основних зразків техніки у визначені терміни, з врахуванням наявного резерву часу. Побудова план-графіку робіт ТО з урахуванням резерву часу, виявленого при аналізі повного щодобового процесу використання техніки за призначенням.

Таким чином, скориставшись даною методикою, можна розрахувати всі необхідні дані для безпосередньої організації робіт ТО і поточного ремонту МІО. А саме, можна обгрунтовано здійснити вибір доцільної стратегії обслуговування МІО, виявити наявні організаційні резерви часу, які можна використати для підвищення ефективності ТО техніки, обгрунтувати необхідність організації робіт ТО в одну, дві або три зміни, забезпечити гарантоване виконання робіт ТО різних видів і поточного ремонту основних зразків МIO на протязі наявного резерву часу, а також визначити доцільні значення періодичності проведення ТО або контролю технічного стану у відповідності з обраною стратегією обслуговування техніки. А все це в сукупності забезпечить можливість підтримання значення коефіцієнту технічного використання інженерної техніки $K_{T B}\left(\tau_{д}\right)$ - комплексного показника надійності МІО на рівні, необхідному для своєчасного виконання інженерним підрозділом поставлених завдань. Питання підвищення ефективності організації і проведення ТО техніки $\epsilon$ надзвичайно актуальним ще й тому, що факт щоденного своєчасного виходу і готовності техніки до виконання завдань контролюється представниками відповідних міжнародних організацій, які мають право накладати певні штрафні санкції у випадках зриву планових робіт.

\section{Література:}

1. Мальченко С.В. Колос О.Л., Солонніков В.Г., Полякова О.В. Використання методу почасового резервування для вдосконалення системи технічного обслуговування техніки як один із способів підвищення іiї надійності в ході виконання завдань підрозділами інженерних військ ЗС України у складі міжнародних миротворчих контингентів. Труди університету. Київ : НАОУ, № 1(91). 2009. С. 121-132.

2. Василенко О.В., Солонніков В.Г., Колос О.Л., Полякова О.В. Застосування теорії почасового резервування для обгрунтування доцільності організації функціонування системи технічного обслуговування за реальним технічним станом техніки інженерних підрозділів 200 
Збройних Сил України, що діють у складі міжнародних миротворчих контингентів. Труди університету. Київ : НАОУ, № 1(95). 2010. C. $182-195$.

3. Солонніков В.Г., Колос О.Л., Полякова О.В. Удосконалення моделі функціонування системи технічного обслуговування техніки підрозділів інженерних військ Збройних Сил України в ході виконання завдань у складі міжнародних миротворчих контингентів засобами почасового резервування. Труди університету. Київ : НАОУ, № 1(94). 2010. C. 234-242.

DOI https://doi.org/10.30525/978-9934-588-79-2-2.49

\title{
ПРОБЛЕМНІ ПИТАННЯ РОЗВИТКУ РАКЕТНО-АРТИЛЕРІЙСЬКОГО ОЗБРОСННЯ ТА ШЛЯХИ ЇХ ВИРІШЕННЯ
}

\author{
Майстренко О. А. \\ кандидат технічних наук, \\ провідний науковий співробітник \\ Центрального науково-дослідного інституту озброєння \\ та військової техніки Збройних Сил Украӥни \\ м. Київ, Украӥна
}

Вступ. Аналіз результатів ведення бойових дій свідчить про те, що ракетно-артилерійське озброєння (РАО) залишаються основним, а іноді єдиним засобом дальнього вогневого ураження противника. Основні втрати, які завдаються противнику, так само, як і втрати наших військ - саме від вогню артилерії.

Аналіз підготовки та виконання завдань 3 вогневого ураження противника підрозділами ракетних військ і артилерії (PBiA) у ході Операції Об'єднаних Сил (ООС) дозволяє визначити низку чинників, що негативно впливають на ефективність бойового застосування в даних умовах.

Зовнішні та внутрішні чинники, що негативно вплинули на ефективність бойового застосування РВіА [1-3]:

- відсутність можливості протидії вогневим підрозділам, що ведуть стрільбу з території суміжної держави; 